\title{
Drainage water management effect on corn planting date in southeast lowa
}

\author{
L. Schott, A. Lagzdins, A.L.M. Daigh, C. Pederson, G. Brenneman, and M.J. Helmers
}

\begin{abstract}
In Iowa, producers achieve an adequate growing season for high yielding corn (Zea mays L.) by beginning field activities in a timely fashion. Subsurface drainage allows for early field activities by improving trafficability and decreasing excess water stress to crops on poorly drained soils. Drainage water management practices reduce drainage volumes and nitrate $\left(\mathrm{NO}_{3}\right)$ loss by maintaining the water table closer to the ground surface when compared to conventional drainage systems. The objective of this study was to determine the effect of shallow, controlled, conventional, and no drainage on depth to water table, volumetric water content, and soil temperature during a 51-day period, from mid-April through May, to evaluate if drainage water management practices delay planting. At the Iowa State University Southeast Research Farm near Crawfordsville, Iowa, we evaluated eight large-scale research plots with two replicates for each of the four drainage treatments over the 51-day planting period during 2012 to 2015. Each plot was planted half to soybeans (Glycine max [L.] Merr.) and the other half to corn, and the halves rotated every year in accordance with a typical corn-soybean rotation. Conventional and controlled drainage significantly lowered $(p<0.05)$ the water table when compared to the undrained treatment over the four-year study period. However, the shallow and undrained treatments significantly increased $(p<0.05)$ daily average soil temperatures at a $10 \mathrm{~cm}$ depth when compared to the conventional and controlled drainage treatments. Drainage treatment did not affect daily volumetric water content, maximum soil temperature, and minimum soil temperature at $10 \mathrm{~cm}$. Overall, drainage treatment did not affect potential planting dates due to similar soil temperatures and volumetric water contents. However, drainage treatment does affect the depth of water table and reduces the risk of excess water stress on the crop during early season periods near planting.
\end{abstract}

Key words: corn—drainage water management—-soil temperature-volumetric water content-water table

\begin{abstract}
Subsurface drains lower shallow water tables and remove excess water from the soil profile of agricultural land in areas with poor natural drainage. These shallow water tables reduce soil aeration, which limits seed germination, cause plant root injury, and reduce the plant's ability to take up nutrients thereby reducing grain yields (Evans and Fausey 1999). When excess water stress occurs soon after planting or during corn (Zea mays L.) establishment, yields are affected more than by water stress during periods later in the growing season (Kanwar et al. 1988). Evans et al. (1991) investigated the effects of soil excess water stress on corn yields and developed a simple yield model using the summation of water table depths within $30 \mathrm{~cm}$ of the surface during a period
\end{abstract}

and Fouss 2001). Bornstein and Hedstrom (1982) concluded that trafficability increased more rapidly in the spring with, rather than without, subsurface drainage by decreasing soil water content below field capacity. However, excessively dry soils will limit seed germination at the time of planting since corn seeds must absorb 30\% of their weight in water for successful germination (Elmore et al. 2014).

Although subsurface drainage benefits crop production and limits the potential for surface runoff, negative environmental impacts exist. Subsurface drainage contributes to the loss of nitrate-nitrogen $\left(\mathrm{NO}_{3}-\mathrm{N}\right)$ from agricultural lands in the Mississippi River Basin and therefore contributes to the hypoxia zone in the Gulf of Mexico (Turner and Rabalais 1994; David et al. 2010). Proposed practices to limit $\mathrm{NO}_{3}-\mathrm{N}$ losses include designing (shallow drainage) or managing (controlled drainage) the subsurface drainage system in order to reduce the drainage volume or to manage the outflow. Shallow drainage systems contain drains installed at a relatively shallow depth (e.g., $0.6 \mathrm{~m}$ ) (Strock et al. 2011). Controlled drainage systems contain drains installed at the conventional depth described earlier (e.g., >1 m) with a control structure that regulates the water table outflow height.

Many reports conclude drainage water management reduces drainage volumes and $\mathrm{NO}_{3}-\mathrm{N}$ losses, but crop yield impacts are inconclusive. Shallow drainage reduced drainage volume and $\mathrm{NO}_{3}-\mathrm{N}$ loss by $20 \%$ to $58 \%$ and $18 \%$ to $49 \%$, respectively, when compared to conventionally drained systems (Sands et al. 2008; Helmers et al. 2012). Using 20 controlled drainage sites across the

of interest $\left(\mathrm{SEW}_{30}\right)$ as well as a multiplicative factor representing crop susceptibility to shallow water tables at various growth stages.

In Iowa, producers achieve an adequate growing season for high yielding corn by beginning field activities in a timely fashion. Subsurface drainage allows for early field activities by improving trafficability and decreasing excess water stress to crops on poorly drained soils. Campbell and O'Sullivan (1991) defined trafficability as the ability of the soil to provide adequate traction for vehicles while withstanding excess compaction. Based on well-known soil moisture to soil strength relationships, a soil's trafficability increases as soil water contents decrease in the upper soil profile (Bornstein and Hedstrom 1982; Earl 1996; Kornecki
Linda Schott is a graduate student in the Department of Biological Systems Engineering at University of Nebraska-Lincoln in Lincoln, Nebraska. Ainis Lagzdins is an associate professor in the Department of Environmental Engineering and Water Management at Latvia University of Agriculture in Jelgava, Latvia. Aaron L.M. Daigh is an assistant professor in the Soil Science Department at North Dakota State University in Fargo, North Dakota. Carl Pederson is an agricultural specialist in the Department of Agricultural and Biosystems Engineering at lowa State University in Ames, lowa. Greg Brenneman is a field specialist in Extension to Agriculture at lowa State University in Ames, lowa. Matthew J. Helmers is a professor in the Department of Agricultural and Biosystems Engineering at lowa State University in Ames, lowa. 
Midwest and Canada, Skaggs et al. (2012) reported an $18 \%$ to $80 \%$ reduction in annual drainage volume and an $18 \%$ to $79 \%$ reduction in $\mathrm{NO}_{3}-\mathrm{N}$ loads when compared to conventional drainage. Additionally, Schott et al. (2017) reported an average 60\% and $61 \%$ reduction in drainage volume and $\mathrm{NO}_{3}$, respectively. However, corn yields from these same sites ranged from a mild yield reduction to an increase of 19\% (Helmers et al. 2012; Skaggs et al. 2012; Schott et al. 2017).

Producers aim to accumulate 50 to 67 growing degree days $\left({ }^{\circ} \mathrm{C}\right.$; GDD) for corn germination; however, soil temperature at 4 $\mathrm{cm}$ needs to meet or exceed $10^{\circ} \mathrm{C}$ in order for corn to germinate (Elmore et al. 2014). Historically, producers thought subsurface drainage would increase soil temperatures in early spring and allow for earlier planting. In a review by Steenhuis and Walter (1986), three main reasons were found for this rationale: (1) evaporation from an undrained field decreases temperature, (2) rainfall increases soil temperature faster in a drained field due to increased infiltration of warm rain water, and (3) more heat is needed to warm a wet field than a dry one due to water's high specific heat capacity. However, very few field studies support this conclusion. Jin et al. (2008) concluded from their field study in northern Minnesota that subsurface drainage significantly increased spring soil temperature, but only at the depth of the subsurface drains.

In Iowa, corn is planted earlier than soybeans (Glycine max [L.] Merr.) since high yielding corn requires a longer growing season. If field conditions delay planting, the risk of high temperatures during pollination is increased, negatively affecting yields. In Iowa, corn must be planted between April 11 and May 31 for producers to qualify for crop insurance (Plastina 2014). The recommended planting window to obtain the highest corn yield potential in southern Iowa is April 17 to May 8 (Elmore 2012). Since planting delays and shallower water tables can reduce crop yields, it is important to understand the effect of drainage and drainage water management during the spring planting window. The objective of this study was to investigate the impact of subsurface drainage and drainage water management practices on volumetric soil water content, soil temperature, and depth to water table in order to evaluate trafficability and crop establishment during the crop insurance planting window for corn in southern Iowa.

\section{Table 1}

Spring field activities for the corn rotation from 2012 to 2015 including control dates for controlled drainage plots. An open control structure indicates the drainage depth is $1.2 \mathrm{~m}$. In the spring, a closed control structure indicates drainage depth is $0.76 \mathrm{~m}$. If a date is not provided, the drainage depth is the spring closed depth.

\begin{tabular}{|c|c|c|c|c|c|c|}
\hline \multirow[b]{2}{*}{ Year } & \multirow{2}{*}{$\frac{\text { Fertilizer }}{\text { Anhydrous }}$} & \multirow{2}{*}{$\frac{\text { Tillage }}{\text { Field cultivate }}$} & \multirow[b]{2}{*}{ Planting } & \multirow{2}{*}{$\frac{\text { Herbicide }}{\text { Preemerge }}$} & \multicolumn{2}{|c|}{ Spring control } \\
\hline & & & & & Open & Close \\
\hline 2012 & Mar. 28 & Apr. 11 & Apr. 18 & Apr. 25 & Apr. 5 & June 14 \\
\hline 2013 & May 2 & May 17 & May 17 & May 17 & - & All year \\
\hline 2014 & Apr. 23 & May 6 & May 6 & May 19 & - & All year \\
\hline 2015 & Apr. 17 & Apr. 29 & Apr. 30 & - & Mar. 31 & May 22 \\
\hline
\end{tabular}

Thus, economic risk of reducing $\mathrm{NO}_{3}$ loss with drainage water management can be better evaluated in the future.

\section{Materials and Methods}

Site Location and Design. Research was conducted at the Iowa State Southeast Research Farm (SERF) near Crawfordsville, Iowa

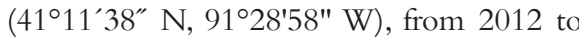
2015.The site was established in 2007 and was part of the USDA National Institute of Food and Agriculture (NIFA) funded Climate and Corn-based Cropping Systems Coordinated Agricultural Project from 2011 to 2015 (https://sustainablecorn.org/). Four drainage treatments of no drainage, conventional drainage, shallow drainage, and controlled drainage were replicated twice across eight large research plots (i.e., 1.2 to 2.4 ha each) whose site map is presented by Schott et al. (2017). The plots were blocked by soil type a silty clay loam Kalona series (fine, smectitic, mesic Vertic Endoaquolls) on the northern plots and a silty clay loam Taintor series (fine, smectitic, mesic Vertic Argiaquolls) on the southern plots. The site is generally flat with no noticeable micro-topography and less than a $5 \mathrm{~m}$ elevation change over the research site (i.e., 17 ha). Each drainage system was designed to have a $1.9 \mathrm{~cm} \mathrm{~d}^{-1}$ maximum drainage coefficient. The conventional and controlled drainage plots have the same drain depth and spacing of 1.2 and $18 \mathrm{~m}$, respectively, whereas the drain depth and spacing in the shallow drainage plots is 0.76 and 12.2 $\mathrm{m}$, respectively.

During 2007 to 2011, each plot was split into halves (north and south) and planted in east to west rows with both corn and soybeans each year. These halves were then rotated each following year to represent a typical corn-soybean rotation in Iowa. In 2012, 24 rows of continuous corn were added on the north edge of block 1 and the south edge of block 2 , resulting in each plot having rotational corn, rotational soy- beans, and continuous corn planted every year. Corn will be the focus of our analysis since corn is typically planted before soybeans in Iowa and requires a longer growing season. Spring field activities included field cultivation, anhydrous ammonia $\left(\mathrm{NH}_{3}\right)$ application, planting, and a preemergence herbicide application (table 1). All drainage treatments were planted on the same day due to plot layout, and the field manager decided when field conditions were suitable for planting. Yield methodology was outlined in Helmers et al. (2012) and reported in Schott et al. (2017). When necessary, the boards in the controlled drainage treatments were removed in mid- to late April for approximately two weeks prior to planting to allow free drainage and replaced in late May to early June after planting. In 2013 and 2014, boards remained closed throughout the year due to low precipitation.

Data Collection. Daily rainfall was measured using a manually read rain gauge located approximately $1 \mathrm{~km}$ from the research plots from 2012 to 2015. Rainfall amounts during the planting periods were calculated by averaging daily manual measurements from the site and rainfall amounts at a National Oceanic and Atmospheric Administration (NOAA) station in Mount Pleasant, approximately $15 \mathrm{~km}$ away. Rainfall data from the NOAA station were used for the long-term average. Daily average, maximum, and minimum temperatures for the site were compiled using the Iowa State Agclimate Network for 2012 to 2013 and Iowa State University Soil Moisture Network for 2014 to 2015 due to the phase out of older weather equipment.

In 2009, water table monitoring wells were installed in the center of each plot where the water table in the drained treatments would be the shallowest and between the rotational corn and soybeans to minimize the impact of farming operations. Depth to water table was monitored hourly using 
Global Water pressure transducers (Global Water, Sacramento, California). Daily average water table depths were calculated as well as the daily minimum depth to water table. The daily minimum water table depths were used to calculate the soil excess water stress in the top $30 \mathrm{~cm}$ of the soil profile $\left(\mathrm{SEW}_{30}\right)$ since crop susceptibility to $\mathrm{SEW}_{30}$ is greatest during the early stages of crop establishment and growth (Kanwar et al. 1988; Evans et al. 1999) (equation 1).

$\mathrm{SEW}_{30}=\sum_{i=1}^{n}\left(30-X_{i}\right)$; if $X_{i} \leq 30$,

where $X_{i}=$ the water table depth below the ground surface in centimeters on the $i$ th day and $n=$ the number of days within the planting window.

Methodologies for measuring soil volumetric water content (VWC) and soil temperature were agreed upon by the USDA-NIFA funded Climate and Cornbased Cropping Systems Coordinated Agricultural Project and followed for this site (Kladivko et al. 2014). Briefly, bulk density samples were collected in 2011 using a modified Uhland sampler for depth increments of 0 to 10,10 to 20,20 to 30,30 to 40,40 to 50 , and 50 to $60 \mathrm{~cm}$ at eight locations transecting each plot and across all three continuous and rotation crop systems. Soil samples were then oven dried at $105^{\circ} \mathrm{C}$ for a minimum of 48 hours (Blake and Hartge 1986). Soil moisture sensors, $\mathrm{ECH}_{2} \mathrm{O} 5 \mathrm{TM}$ (Decagon, Pullman, Washington), were installed in the center of the continuous corn portion of each plot in May of 2011. The soil VWC and temperature were measured at five depths: 10, 20, 40, 60, and $100 \mathrm{~cm}$. However, only the top depth was used for this paper since corn is planted at a depth of $4 \mathrm{~cm}$. Soil VWC and temperature were recorded at five minute intervals using an Em50 data logger. Soil porosity was calculated for the $10 \mathrm{~cm}$ depth using the bulk density samples collected in each plot in 2011 and assuming a mineral density for quartz $\left(2.65 \mathrm{~g} \mathrm{~cm}^{-3}\right)$. Maximum soil moisture values were capped to individual plot soil porosity at the sensor depth increments. Daily average soil moisture and temperature were calculated for the $10 \mathrm{~cm}$ depth. Using bulk density samples collected in 2013, the soil water retention curve for soil samples corresponding to the 0 to $10 \mathrm{~cm}$ depth was determined using a simultaneous collection system for pressure potentials of $-50,-100$,

\section{Figure 1}

Average soil water retention curve for the silty clay loam soils found in the research plots. Field capacity is defined as the volumetric water content at $100 \mathrm{~cm}$ water of capillary pressure head.

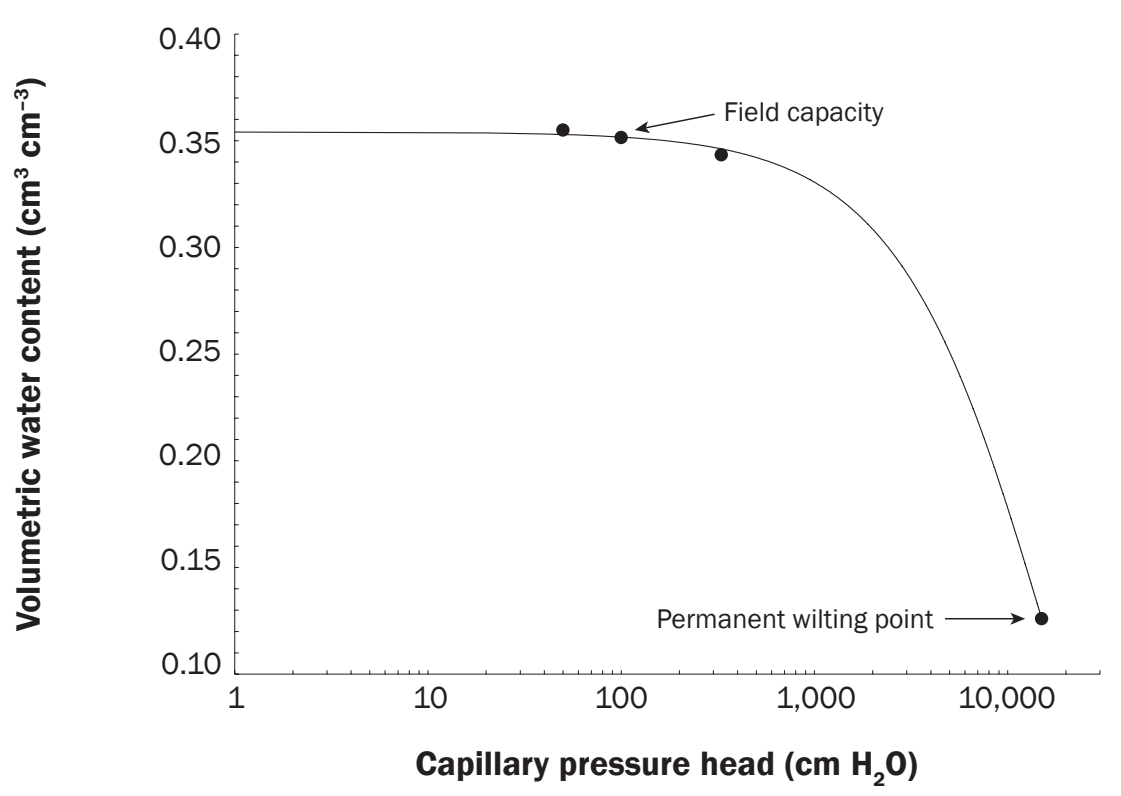

and $-330 \mathrm{~cm}$ water (Powers et al. 1999). The permanent wilting point was defined at $-15,000 \mathrm{~cm}$ water and was determined using a WP4C Water Potential Meter (Decagon, Pullman, Washington). Field capacity is the soilVWC after a rain event when previously saturated soils no longer drain by gravity. Field capacity at this site was defined at a matric potential of $-100 \mathrm{~cm}$ water due to the shallow water tables. Due to site homogeneity, the soil water retention curves were averaged for 0 to $10 \mathrm{~cm}$ representing the entire site (figure 1). Research data were uploaded to the team's central database with review and quality control performed by database managers to ensure data integrity and adherence to standardization (Herzmann et al. 2014).

Statistical Analysis. The experimental design was a randomized complete block design for the drainage treatments. Statistical analyses were conducted using Statistical Analysis System software (version 9.4 SAS 2011). The generalized linear mixed model (GLIMMIX) procedure was used to analyze treatment effects for repeated measurements on the following soil measurements at 10 $\mathrm{cm}$ : daily average VWC, daily average temperature, daily maximum temperature, daily minimum temperature, and daily temperature amplitude. The same procedure was also used to analyze the daily average depth to water table. Replication was set as the random effect for the soil measurements and depth to water table. Means were separated at the 0.05 level using the Tukey method. The general linear model (GLM) procedure was used with two replicates per treatment to analyze treatment effects on $\mathrm{SEW}_{30}$, and the mean values were separated using a least significance difference (LSD) test at the 0.05 level $\left(\operatorname{LSD}_{0.05}\right)$.

\section{Results and Discussion}

Climate. Average air temperatures during the planting window of April 11 to May 31 from 2012 to 2015 varied little from the 25 -year average of $14.7^{\circ} \mathrm{C}$ and ranged from $13.6^{\circ} \mathrm{C}$ to $16.2^{\circ} \mathrm{C}$ (table 2 ). However, the site experienced $24 \%$ to $42 \%$ fewer accumulated GDD as compared to the 25-year average for corn during the planting window in all four years of the study. Every year, except 2013, the site received less than the 25-year average rainfall of $20.16 \mathrm{~cm}$; there was 3\%, 32\%, and $16 \%$ less rainfall during 2012, 2014, and 2015, respectively, and 75\% more rainfall during 2013. It is important to note that there were droughts in the latter halves of 2012 and 2013.

Volumetric Water Content. Soil VWC at $10 \mathrm{~cm}$ depth did not significantly differ between drainage treatments for any day or when averaged across all four years of the study (figure 2). All treatments responded similarly to rainfall during the majority of 
both wetting and drying periods. Although not significant, VWC often tended to fall from greatest to least in the order of no drainage, conventional drainage $(1.2 \mathrm{~m}$ depth; 18 $\mathrm{m}$ spacing), controlled drainage ( 0.76 or 1.2 $\mathrm{m}$ depth; $18 \mathrm{~m}$ spacing), and shallow drainage (0.76 $\mathrm{m}$ depth; $12.2 \mathrm{~m}$ spacing) for the numerical averages. Daily VWC varied the greatest during the planting window in 2013 due to high rainfall with adequate time for drying between events. Comparatively, daily VWC varied little during both 2014 and 2015 because rainfall events were smaller and closer together than in 2013.

In all four years, corn was planted when visual observations indicated the field conditions would allow for good trafficability. When analyzing VWC, soil moisture at 10 $\mathrm{cm}$ was between 0.25 and $0.30 \mathrm{~cm}^{3} \mathrm{~cm}^{-3}$ during planting each year. Therefore, the VWC at this depth was below field capacity, defined at a $-100 \mathrm{~cm}$ water matric potential, for this soil type. Earl (1997) concluded that as VWC decreases below field capacity, trafficability increases. Reasonably, therefore, these results are consistent with this conclusion since corn was planted when the soil was trafficable.

Soil Temperature. Soil temperatures at 10 $\mathrm{cm}$ significantly differed between drainage treatments. Shallow drainage had significantly warmer soil temperatures than the controlled drainage during the last three weeks of the planting window in 2012-a period when the average soil temperatures were the warmest over the entire study period (figure 3). This is consistent with the slightly drier, although not significantly different, soil VWC values (figure 2). However, the undrained treatment was significantly and unexpectedly warmer than the controlled drainage treatment during the second-to-last week of the planting window. For the last few days in April of 2013, when the average temperature drastically increased, the undrained and shallow drainage treatments were significantly warmer than the controlled drainage treatment. The undrained treatment was also significantly warmer than the controlled drainage treatment during the middle of May in the same year. No significant differences occurred in soil temperature in 2014 and 2015 when rainfall was the lowest and air temperatures were slightly above the 25-year average.

Soil temperatures at $10 \mathrm{~cm}$ were, on average, $2^{\circ} \mathrm{C}$ warmer in the shallow drainage and

\section{Table 2}

Average air temperature $\left({ }^{\circ} \mathrm{C}\right)$, accumulated growing degree days (GDD) for a $10^{\circ} \mathrm{C}$ baseline temperature, and rainfall $(\mathrm{mm})$ at the lowa State Southeast Research Farm during the planting window for 2012 to 2015, including a 25-year long-term average.

\begin{tabular}{llll}
\hline Year & Air temperature $\left({ }^{\circ} \mathbf{C}\right)$ & GDD & Rainfall $(\mathbf{m m})$ \\
\hline 2012 & 16.2 & 333 & 196.5 \\
2013 & 13.6 & 254 & 351.8 \\
2014 & 15.1 & 299 & 137.3 \\
2015 & 15.6 & 304 & 168.3 \\
$25-y e a r$ average & 14.7 & 436 & 198.8
\end{tabular}

undrained treatments than in the controlled and conventionally drained treatments. These results are not intuitive. Although not significant,VWC for the no drainage treatment was the wettest and the shallow drainage treatment was the driest. A higher volumetric heat capacity in the undrained treatment would have led to cooler temperatures, not warmer (Steenhuis and Walter 1986). Additionally, while Jin et al. (2008) reported warmer temperatures in shallow drainage, the difference was only at the depth of drainage and not near the surface. Therefore, the reason why the shallow drainage and undrained treatments are warmer remains an open question.

Corn planting occurred the earliest of all four years in 2012 when the average air temperatures were the warmest and the average soil temperature across all treatments was $15^{\circ} \mathrm{C}$. In contrast, corn planting occurred the latest of all four years in 2013 due to high rainfall. Although rainfall delayed the planting of corn in 2013, average soil temperature was $21^{\circ} \mathrm{C}$ on the planting date $-7^{\circ} \mathrm{C}$ warmer than in 2012 on the date of planting corn. While the increase in average soil temperature of the shallow and undrained treatments could allow for earlier planting, the differences occurred later in the planting window when soil temperatures were already above $10^{\circ} \mathrm{C}$.

The daily maximum soil temperatures at $10 \mathrm{~cm}$ did not significantly differ between drainage treatments when averaged across the planting window and year. However, some notable daily differences were observed. The maximum daily soil temperature at $10 \mathrm{~cm}$ was the warmest in the shallow and undrained treatments in 2012 and 2013 (figure 4). Sporadic days throughout both years exist where the maximum temperature at $10 \mathrm{~cm}$ in the undrained treatment was significantly warmer than the controlled drainage treatment. There were also a few instances in both years when the maximum temperature at $10 \mathrm{~cm}$ in the shallow drained treatment was also significantly warmer than the controlled drainage treatment. These differences tended to occur when the soil temperature increased rapidly, such as at the end of the planting window during 2012 and midplant window during 2013. The maximum soil temperature at $10 \mathrm{~cm}$ was between $3^{\circ} \mathrm{C}$ and $5^{\circ} \mathrm{C}$ warmer in the shallow drainage and undrained treatments, but just like the differences in average soil temperature at 10 $\mathrm{cm}$, they tended to occur later in the planting window when soil temperatures were already warm. The undrained treatment also tended to have the highest maximums in 2014. The undrained treatment was significantly warmer than the shallow drainage treatment few times during the end of the 2014 planting window. No clear differences were evident in 2015

Daily minimum soil temperature at 10 $\mathrm{cm}$ did not statistically differ between drainage treatments during the four planting windows. However, differences in daily minimum soil temperature occurred for two time periods. During the first week of May of 2012, the daily minimum soil temperature at $10 \mathrm{~cm}$ in the conventional drainage treatment changed from significantly warmer than the other three treatments to significantly cooler than the others (figure 5). Then, in early May of 2013, the undrained and shallow drainage treatments had significantly warmer minimum temperatures than the conventionally drained treatment for a few days. In all four years, corn was planted when the daily minimum soil temperatures at $10 \mathrm{~cm}$ were above the $10^{\circ} \mathrm{C}$ necessary for seed germination.

Water Table. Drainage treatments differed in depth to water table. In all four years, the water tables in the undrained and shallow drainage treatments were the shallowest and the conventional and controlled drainage treatments were the deepest (figure 6). Overall, water tables were deepest in 2014 and shallowest in 2013.

In 2012, prior to the large rain event in early May, the undrained treatment had a significantly shallower water table than the 


\section{Figure 2}

Average daily volumetric water content $\left(\mathrm{cm}^{3} \mathrm{~cm}^{-3}\right)$ at $10 \mathrm{~cm}$ depth and daily rainfall amounts $(\mathrm{mm})$ with the date of planting indicated for the planting windows in (a) 2012, (b) 2013, (c) 2014, and (d) 2015 for all drainage treatments. Lack of data due to instrumentation difficulties in the controlled drainage treatment was observed in 2013 and 2014.
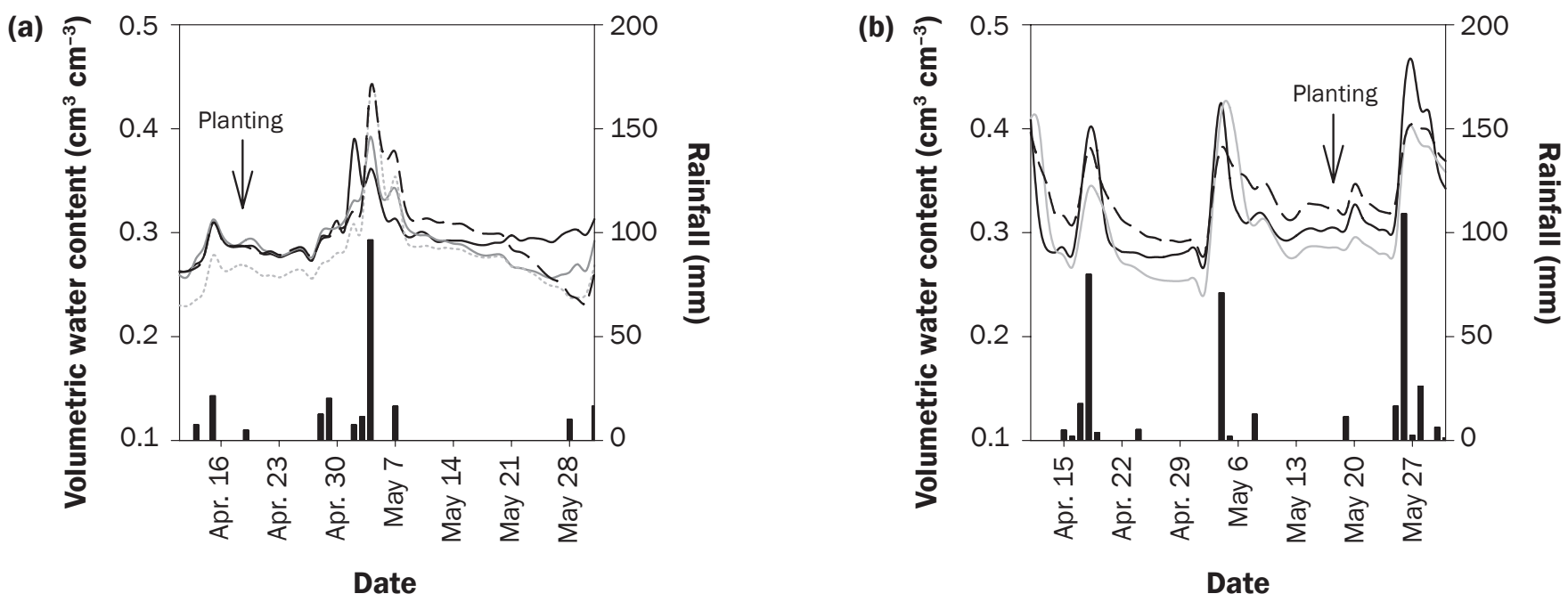

(c)

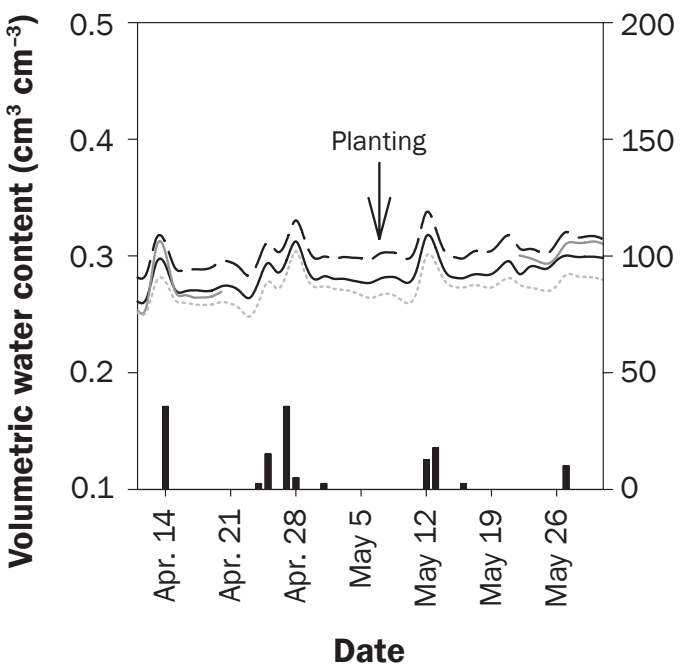

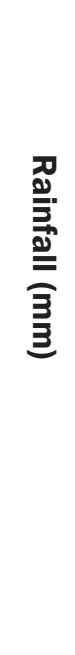

(d)

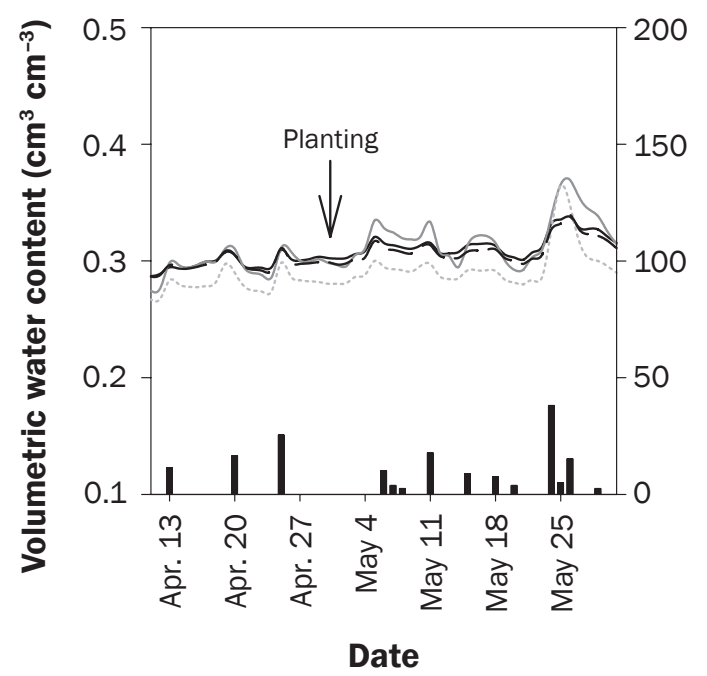

\section{Legend}

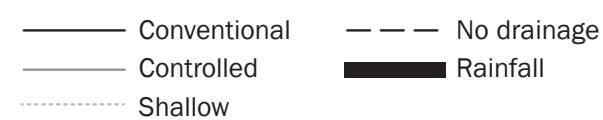

deepest water table, which was the controlled drainage treatment. There were no significant differences between treatments at the end of April through early May due to a week of rainfall. Nearly all treatments were significantly different from one another immediately following the rainfall event, however. By the end of the planting window in 2012, only the undrained treatment was significantly shallower than the controlled and conventional drainage treatments.
In 2013, the water table in the undrained treatment was significantly shallower than the other three treatments for most of the planting window. Since the boards in the controlled drainage treatment were maintained at $0.76 \mathrm{~m}$ during 2013, the other three treatments only significantly differed from each other immediately following rainfall. The undrained treatment was also significantly shallower than the controlled and conventional drainage treatments for most of 2014.
During 2015, the shallow and undrained treatments had a significantly shallower water table than the other two treatments.

In most years, there were no differences between the controlled and conventional drainage treatments. These results are expected since this is the period of time when there is no water table management in the controlled drainage treatment. In 2013, when the water table control boards were maintained at $0.76 \mathrm{~m}$, and there was sub- 


\section{Figure 3}

Average daily soil temperature $\left({ }^{\circ} \mathrm{C}\right)$ at $10 \mathrm{~cm}$ depth with the date of planting indicated for the planting windows in (a) 2012, (b) 2013, (c) 2014, and (d) 2015 for all drainage treatments.

(a)

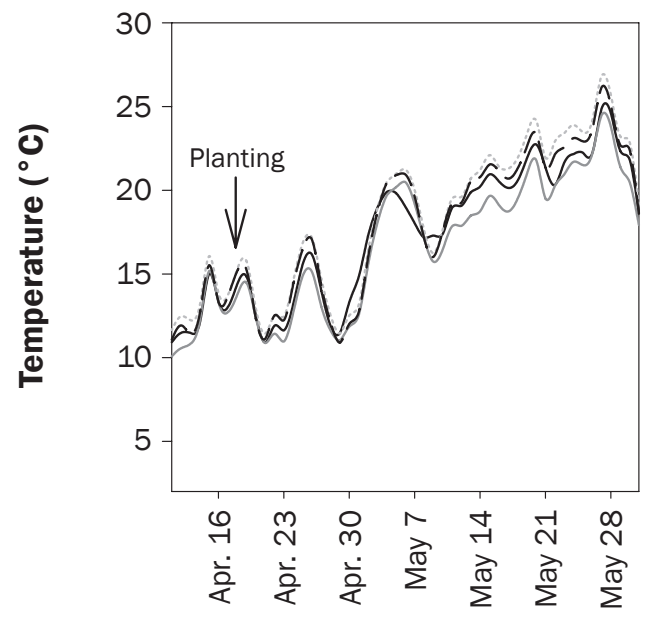

Date

(c)

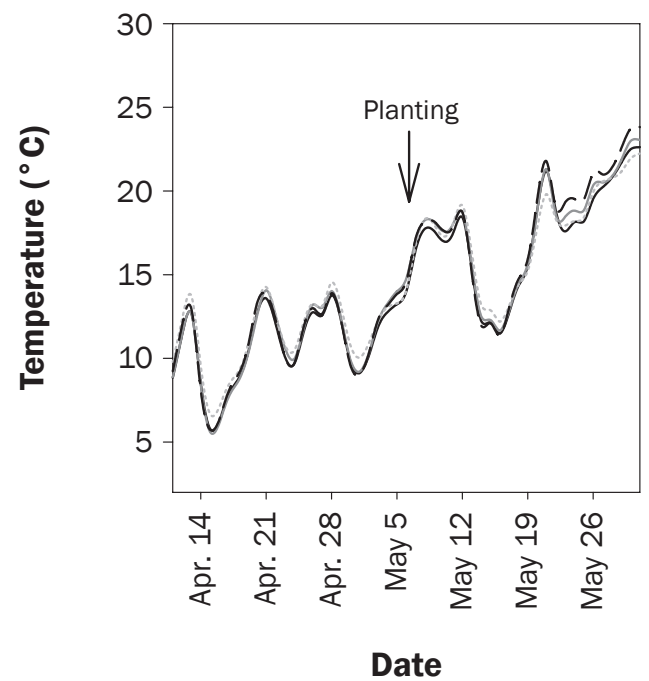

(b)

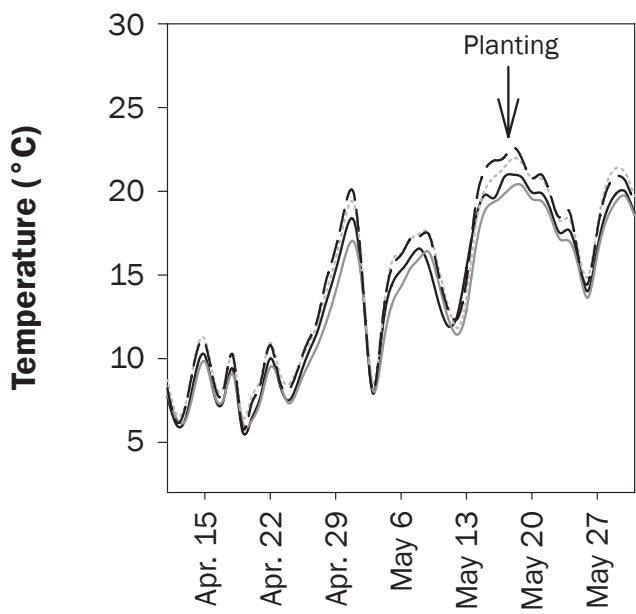

Date

(d)

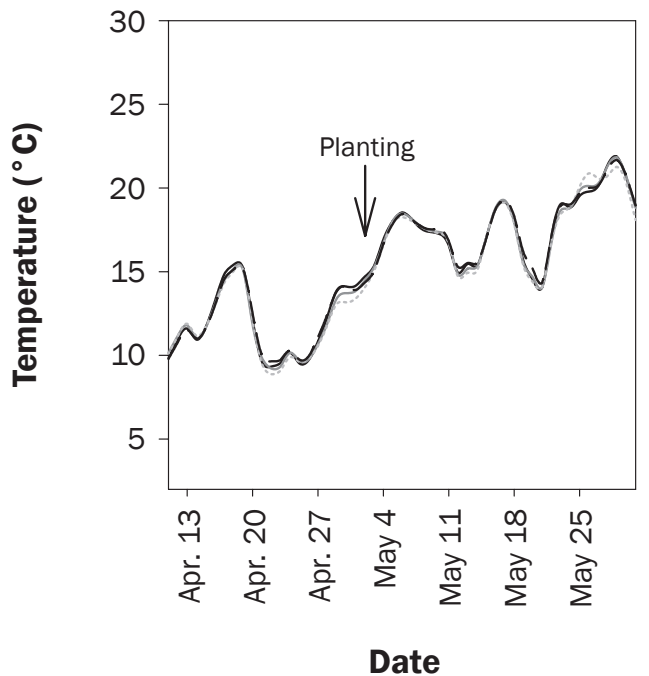

\section{Legend}

stantial rainfall during the planting window, the water table in the controlled drainage treatment was shallower than the conventional treatment but deeper than the shallow drainage treatment. There were also several instances in 2012, 2013, and 2015 when the water table in the undrained treatment was at the surface, which likely reduced trafficability and would negatively impact crop establishment due to reduced soil aeration (Evans and Fausey 1999). The water tables in the other three drainage treatments also rose near the surface in 2012 and 2013 but receded faster. The water table monitoring wells were located in the center of each plot between two tile lines where the water table would be the shallowest. The wells in the undrained plots were also placed in the center of each plot and not necessarily where the water table would be the shallowest. Therefore, the water tables in the undrained plots could be shallower than the data available.

Initial logic would indicate that since there were significant differences in the depth to water table between drainage treatments, there would also be significant differences between VWC. Theoretically, the VWC in the undrained and shallow drainage treatments would be higher than the VWC in the controlled and conventionally drained treatments (Skaggs and Chescheir 2003). However, this was not the case in this study. This inconsistency can be explained with the soil water retention curve, which has little differences in VWC between -50 and -330 $\mathrm{cm}$ water matric potentials for this soil type (figure 1). Therefore, the rise of water height in this soil's network of pores is similar for all water table depths to at least $3.3 \mathrm{~m}$ after 
Figure 4

Maximum daily soil temperature $\left({ }^{\circ} \mathrm{C}\right)$ at $10 \mathrm{~cm}$ depth with the date of planting indicated for the planting windows in (a) 2012, (b) 2013, (c) 2014 , and (d) 2015 for all drainage treatments.

(a)

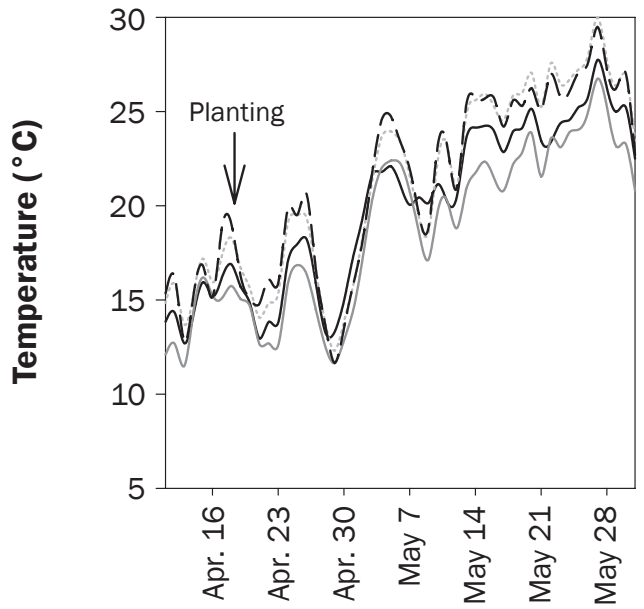

Date

(c)

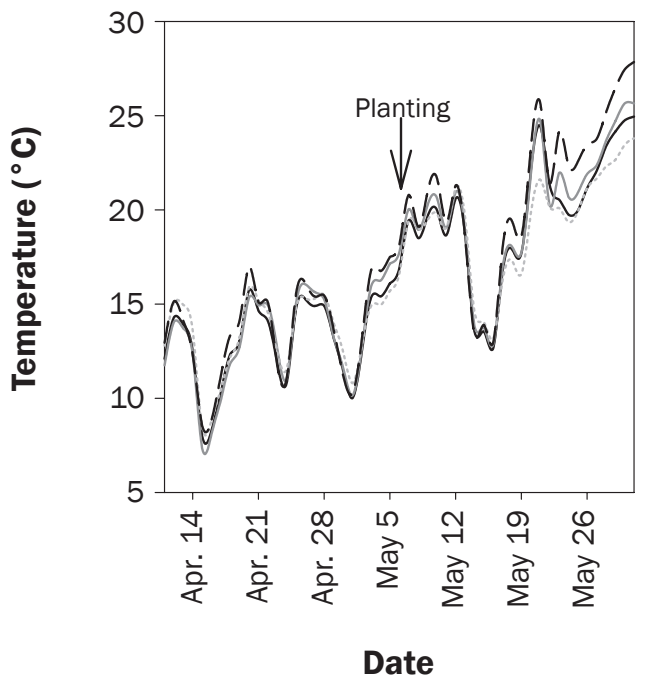

(b)

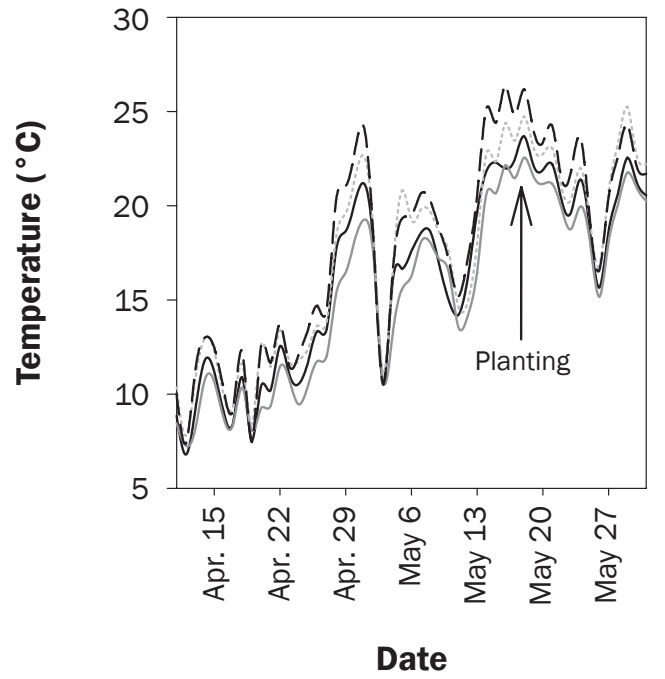

(d)

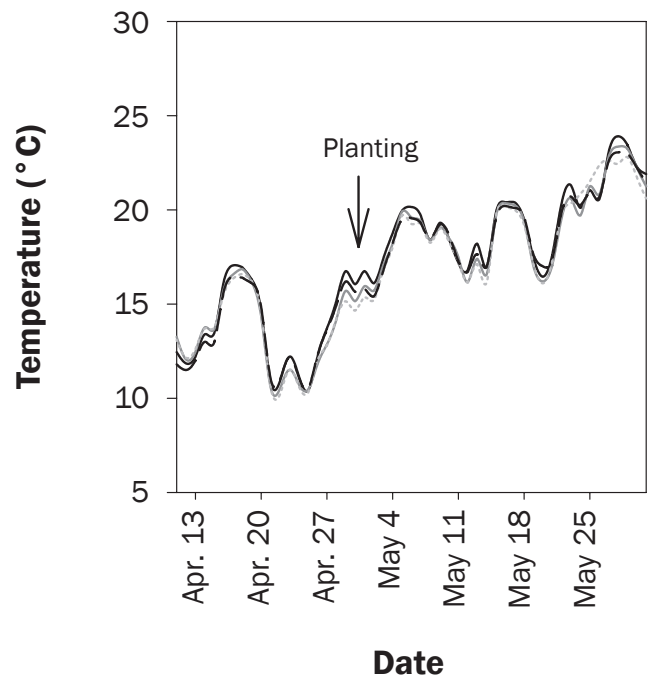

Legend

Conventional

Controlled

Shallow

No drainage

drainage of gravitational water. The lack of difference in VWC could also be explained by the fact that the soil sensors are point measurements in a large field and with only two replicates, whereas the water table depth measurements are influenced by the entire field and not just a point. Therefore, the water tables depth measurements likely give a more precise field average value than the point measurements of the 5TE soil moisture sensors.

Soil Excess Water Stress. On average, the undrained treatment had the greatest $\mathrm{SEW}_{30}$ during the entire planting window followed by the shallow drainage treatment (table 3 ). Over all four years, $\mathrm{SEW}_{30}$ was over 2,000\% greater in the undrained plots than the conventional and controlled drainage treatments.

Results for $\mathrm{SEW}_{30}$ after planting were similar to those for $\mathrm{SEW}_{30}$ during the whole planting window (table 4). When corn was planted the earliest of all four years in 2012, all $\mathrm{SEW}_{30}$ occurred after planting. When corn was planted the latest of all four years in 2013, all treatments had less $\mathrm{SEW}_{30}$ after planting compared to the entire planting window; the shallow and controlled drainage treatments had nearly half their $\mathrm{SEW}_{30}$ after planting than in the entire planting window. Since Iowa receives much of its rainfall in April through June, planting date is heavily dependent on the timing of rainfall. Crop susceptibility to $\mathrm{SEW}_{30}$ is greatest during the early stages of crop establishment and growth (Kanwar et al. 1988; Evans et al. 1999).

Interestingly, both 2014 and 2015, which had the least $\mathrm{SEW}_{30}$ during the planting window, were the only years of this analysis that had corn yield reductions (table 5; Schott 


\section{Figure 5}

Minimum daily soil temperature $\left({ }^{\circ} \mathrm{C}\right)$ at $10 \mathrm{~cm}$ depth with the date of planting indicated for the planting windows in (a) 2012, (b) 2013, (c) 2014, and (d) 2015 for all drainage treatments.

(a)

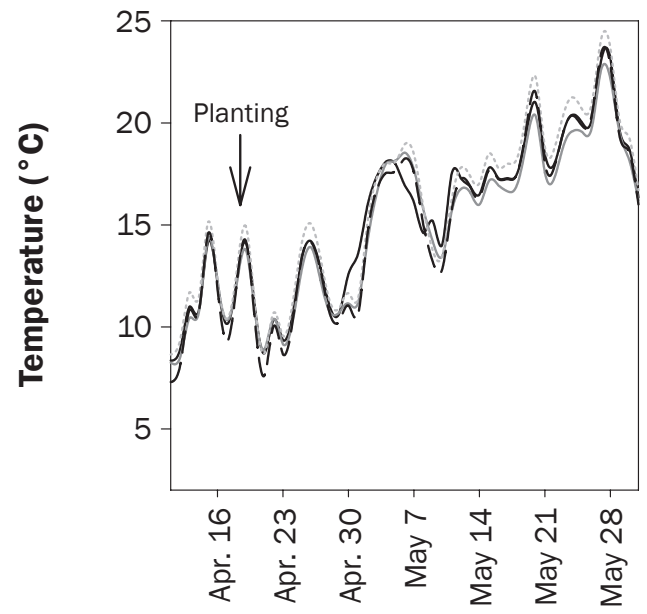

Date

(c)

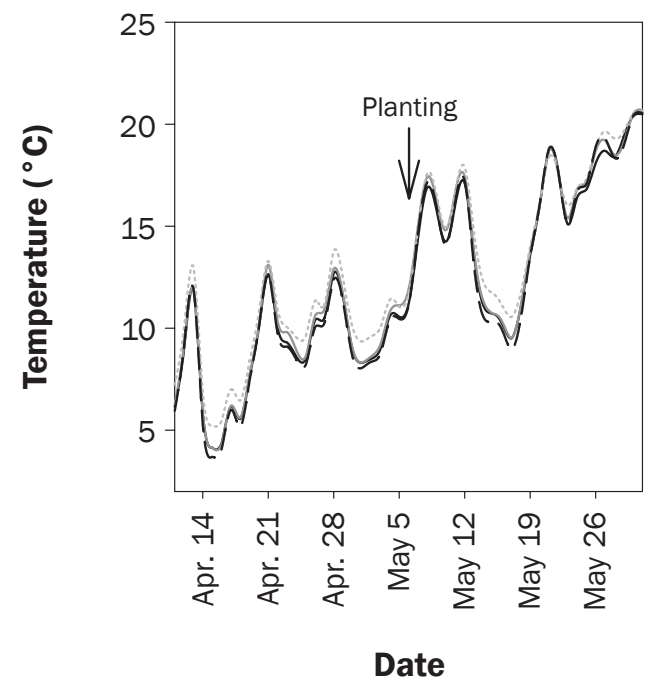

(b)

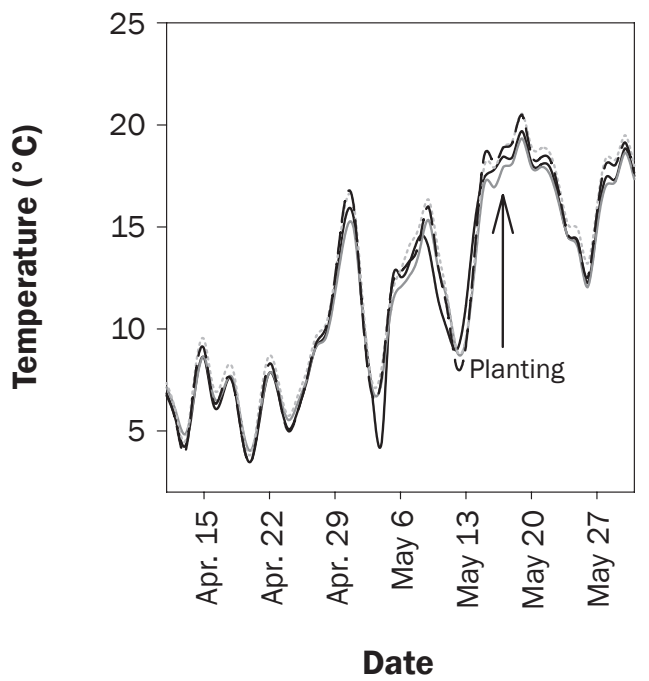

(d)

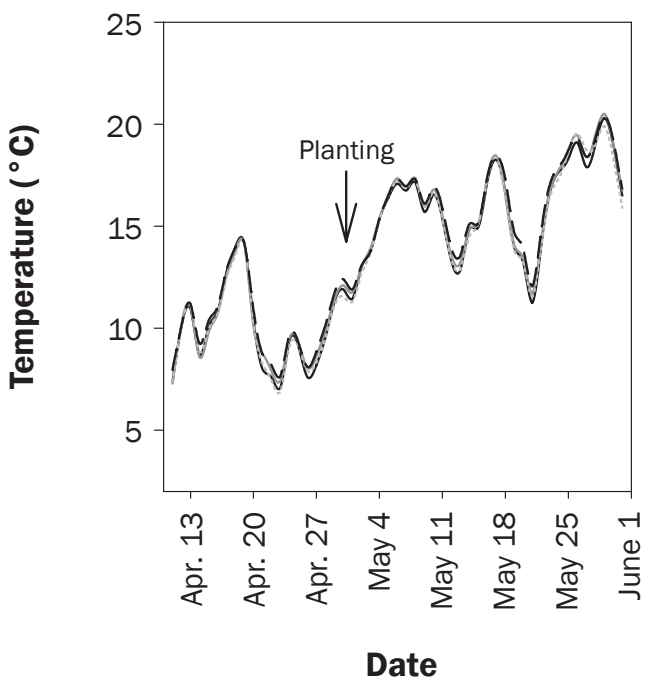

\section{Legend}

et al. 2017). Corn yields in the undrained treatment were $4 \%$ and $16 \%$ less than in the conventional drainage treatment in 2014 and 2015, respectively. Although yields do not seem to be associated with $\mathrm{SEW}_{30}$ during this time period, the majority of planting periods investigated had below average rainfall. Even though 2013 had above average rainfall during the planting period, the remainder of the growing season had well below average precipitation. Drought stress during most of 2013 may have overshadowed $\mathrm{SEW}_{30}$ during the critical time after the corn was planted.
Drainage Effect on Planting Date. When each plot had aVWC at $10 \mathrm{~cm}$ depth below field capacity (Earl 1997), average soil temperature at $10 \mathrm{~cm}$ above $10^{\circ} \mathrm{C}$ (Elmore et al. 2014), and a water table deeper than $30 \mathrm{~cm}$ (Kanwar et al. 1988; Evans et al. 1999), the plot was deemed suitable for planting. Using the first day when both drainage plots within a treatment would be suitable for planting, a theoretical target planting date was determined. For the years 2012, 2014, and 2015, the target planting dates for all treatments would have been April 11 or 12. In 2013, the conventionally drained and shallow drainage treatments' target planting date would have been on April 14 or 15 . However, the target planting date for the undrained treatment was not until nearly two weeks later on April 26 due to shallow water tables. Lack of VWC data in the controlled drainage treatment in 2013 and 2014 prevented its inclusion in the target planting date analysis in these two years.

All of these target dates of planting occurred well before the actual dates of planting done in this study. Only one day of fieldwork was allotted to determine the 


\section{Figure 6}

Average daily depth to water table $(\mathrm{m})$ and daily rainfall amounts $(\mathrm{mm})$ with the date of planting indicated for the planting windows in (a) 2012 , (b) 2013, (c) 2014, and (d) 2015 for all drainage treatments.

(a)

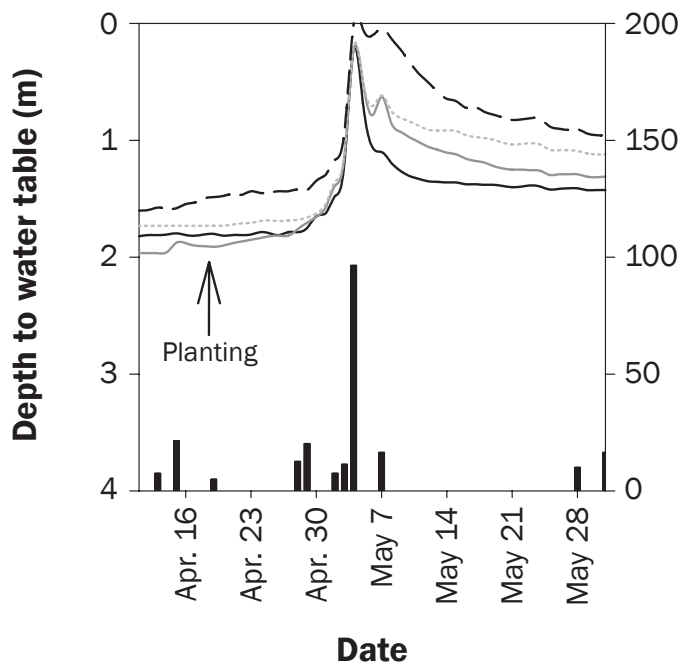

(c)

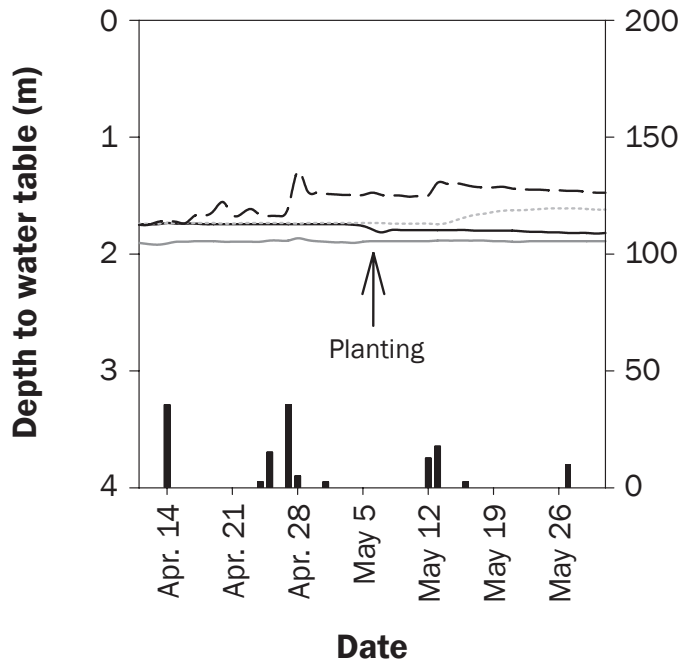

(b)

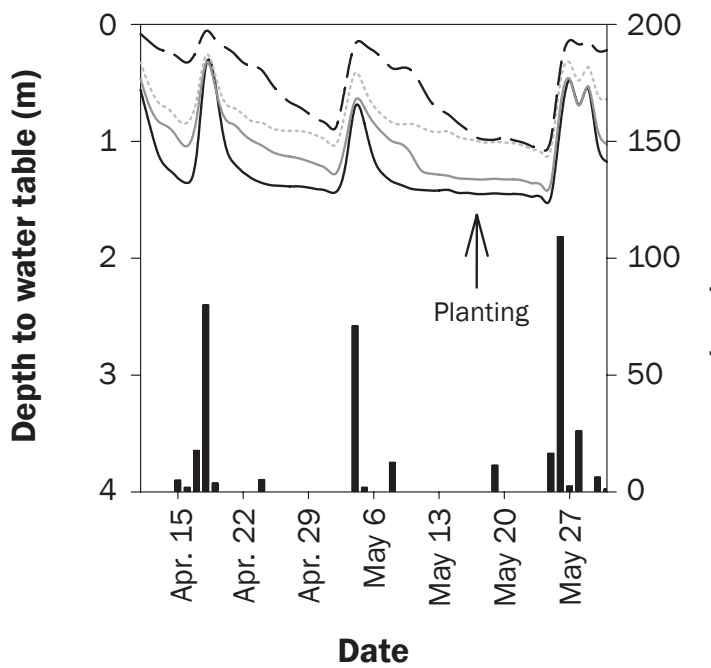

Legend

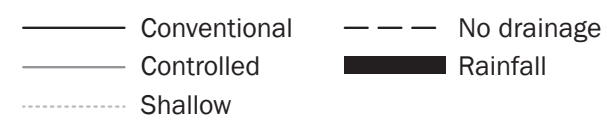

(d)

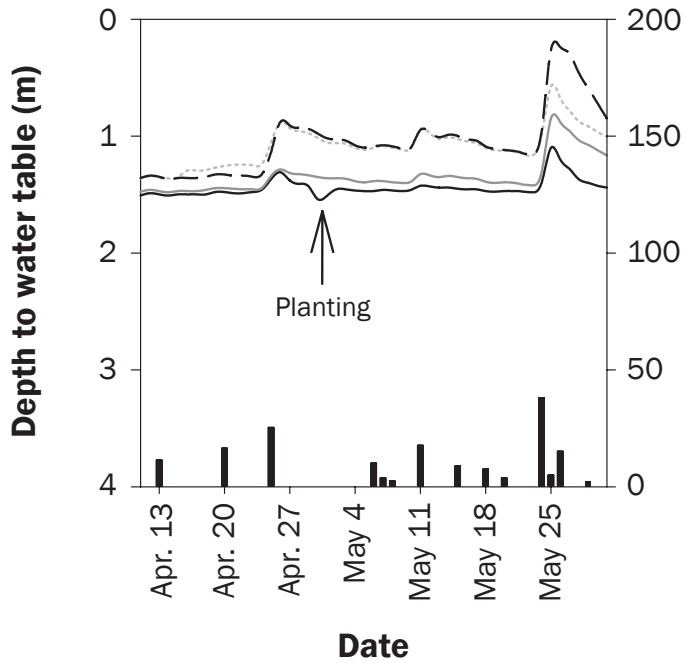

target planting date because all planting activities can be completed in one day in this study. However, producers managing larger areas for corn would need a longer window of time to complete field operations. Smaller farms will be able to target these dates more effectively than large farms that take multiple days or weeks to accomplish. However, these large farms can improve their ability to meet target planting dates by implementing time-saving soil management practices (e.g., reduced tillage and use of newer planting technologies) (Kucharik 2006). The water table in the undrained plots may also be shallower than the data available due to the location of the water table elevation wells, which could delay planting more than discussed previously. However, only the wet year would have had a planting delay in the undrained treatment. Producers may also be hesitant to plant on the first day of the planting window due to high risk of additional cold weather and frost. Nevertheless, early planting is well known to increase profits by allowing crops to reach full maturity before a killing frost and maximizing time for in-field drying (Lauer et al. 1999). Additionally, corn hybrids can be selected that have greater resilience to early season suboptimal temperatures (Gupta 1985).

At this site, drainage volumes and $\mathrm{NO}_{3}$ loss were reduced by $60 \%$ and $61 \%$ for the controlled drainage treatment and 58\% and $49 \%$ for the shallow drainage treatment, respectively, when compared to conventional drainage for the five-year period from 


\section{Table 3}

Soil excess water stress at $30 \mathrm{~cm}$ during planting window from 2012 to 2015 for all drainage treatments. Means within years or four-year average with a different letter are significantly different $(p<0.05)$. Only years with significant differences have letters included.

\begin{tabular}{lllcc}
\hline Year & Conventional & Controlled & Shallow & No drainage \\
\hline 2012 & 19 & 16 & 68 & 163 \\
2013 & 2 & 14 & 185 & 328 \\
2014 & 0 & 0 & 0 & 0 \\
2015 & 0 & 0 & 23 & 12 \\
Average & $5 b$ & $7 b$ & $69 a b$ & $126 a$
\end{tabular}

\section{Table 4}

Soil excess water stress at $30 \mathrm{~cm}$ after planting was completed from 2012 to 2015 for all drainage treatments. Means within years or four-year average with a different letter are significantly different $(p<0.05)$. Only years with significant differences have letters included.

\begin{tabular}{llllc}
\hline Year & Conventional & Controlled & Shallow & No drainage \\
\hline 2012 & 19 & 16 & 68 & 163 \\
2013 & 0 & 10 & 83 & 92 \\
2014 & 0 & 0 & 0 & 0 \\
2015 & Ob & Ob & $23 a$ & $1 b$ \\
Average & 5b & $6 b$ & $44 a b$ & $64 a$
\end{tabular}

\section{Table 5}

Corn yields $\left(\mathrm{Mg} \mathrm{ha}^{-1}\right)$ from 2012 to 2015 for all drainage treatments. Means within years with a different letter are significantly different $(p<0.05)$. Only years with significant differences have letters included.

\begin{tabular}{lcccc}
\hline Year & Conventional & Controlled & Shallow & No drainage \\
\hline 2012 & 12.5 & 11.9 & 11.5 & 11.6 \\
2013 & 9.1 & 8.4 & 8.4 & 8.7 \\
2014 & $13.7 \mathrm{a}$ & $13.7 \mathrm{a}$ & $13.4 \mathrm{ab}$ & $13.1 \mathrm{~b}$ \\
2015 & $14.3 \mathrm{a}$ & $13.1 \mathrm{a}$ & $13.8 \mathrm{a}$ & $11.9 \mathrm{~b}$ \\
\hline
\end{tabular}

2011 to 2015 (Schott et al. 2017). Thus, at this site, drainage water management substantially reduced $\mathrm{NO}_{3}$ loss without delaying planting or reducing yields. However, the years investigated by Schott et al. (2017) had average and below average annual rainfall. Helmers et al. (2012) reported while controlled drainage reduced $\mathrm{NO}_{3}$ loss by $36 \%$, corn yields were also reduced by $6 \%$ when the growing season was characterized by above average rainfall. While a planting date analysis is not possible for these years, it highlights the need for further analyses of drainage water management practices on planting dates during years with high frequency and quantity precipitation events in the spring months when water tables would persist above the drains for extended periods.

\section{Summary and Conclusions}

Drainage treatment did not impact the planting date of corn with respect to soil temperature and VWC since minor soil tem- perature differences exist in the early part of the planting window, and there were no differences in VWC between treatments. However, drainage treatment does impact the date of planting with respect to the depth of water table. From the analyses discussed, the undrained treatment would have been delayed in planting in one year of four years studied. Shallow water tables after rain events, like in 2012 and 2013, in all three drainage treatments receded back to drain depth in a few days, which is the same time period that the VWC were above field capacity. More investigation would be useful to determine if drainage treatment affects yields in terms of $\mathrm{SEW}_{30}$, during years with high frequency and quantity precipitation events in the spring months when water tables would persist above the drains for extended periods.

This study highlights that various drainage designs (i.e., with the same drainage coefficient) equally produce soil conditions for early planting, whereas undrained soils will affect planting date during wet years. Additionally, the controlled $(0.76$ or 1.2 $\mathrm{m}$ depth and $18 \mathrm{~m}$ spacing) and shallow (0.76 $\mathrm{m}$ depth and $12.2 \mathrm{~m}$ spacing) drainage reduced $\mathrm{NO}_{3}$ movement off field as compared to conventional drainage $(1.2 \mathrm{~m}$ depth and $18 \mathrm{~m}$ spacing) at the same research site that was used for the analyses presented here. Therefore, controlled or shallow drainage would be preferable drainage options for producers aiming to reduce $\mathrm{N}$ losses in drainage waters without compromising yield potentials due to planting date.

\section{Acknowledgements}

This research was funded in part by the regional collaborative project supported by the USDA National Institute of Food and Agriculture (NIFA), Award No. 2011-6800230190, Cropping Systems Coordinated Agricultural Project: Climate Change, Mitigation, and Adaptation in Corn-based Cropping Systems. Research data and supporting metadata are stored in the team's centralized Climate and Cropping Systems database.

\section{References}

Blake, G.R., and K.H. Hartge. 1986. Bulk density. In Methods of Soil Samples, ed. A. Klute, 363-375. Part

1. 2nd ed. Agronomy Monograph 9. Madison, WI: American Society of Agronomy.

Bornstein, J., and W.E. Hedstrom. 1982. Trafficability factor in a silty clay loam soil. Transactions of the American Society of Agricultural Engineers 25(5):1240-1244.

Campbell, D.J., and M.F. O'Sullivan. 1991. The Cone Penetrometer in Relation to Trafficability, Compaction, and Tillage. In Soil Analysis: Physical Methods, ed. K.A. Smith and C.E. Mullins, 399-429. New York, NY: Marcel Dekker.

David, M., L. Drinkwater, and G. Mclsaac. 2010. Sources of nitrate yields in the Mississippi River Basin. Journal of Environmental Quality 39:1657-1667.

Earl, R. 1997. Prediction of trafficability and workability from soil moisture deficit. Soil and Tillage Research 40:155-168.

Elmore, R. 2012.Best Corn Planting Dates for Iowa. Integrated Crop Management News. http://www.extension.iastate. edu $\backslash$ CropNews $\backslash 2012 \backslash 0327$ elmore2.htm

Elmore, R., M. Al-Kaisi, and M. Hanna. 2014. Corn Seeding Depth: Back to Basics. Agronomy News, Volume 5, Issue 1. Cambridge, MD: University of Maryland Extension. https://extension.umd.edu/sites/extension.umd.edu/ files/_docs/Agronomy\%20News\%20May\%201\%20 2014.pdf.

Evans, R.O., R.W. Skaggs, and R.E. Sneed. 1991. Stress day index models to predict corn and soybean relative yield under high water table conditions. American Society of Agricultural Engineers 34(5):1997-2005. 
Evans, R.O., and N.R. Fausey. 1999. Effects of Inadequate Drainage on Crop Growth and Yield. In Agricultural Drainage, eds. Skaggs, R.W. and J. van Schilfgaarde, 13-54. Agronomy Monograph 38. Madison, WI: American Society of Agronomy, Crop Science Society of America, and Soil Science Society of America.

Gupta, S.C. 1985. Predicting corn planting dates for moldboard and no-till tillage systems in the Corn Belt. Agronomy Journal 77(3):446-455.

Helmers, M.J., R. Christianson, G. Brenneman, D. Lockett, and C. Pederson. 2012. Water table, drainage, and yield response to drainage water management in southeast Iowa. Journal of Soil and Water Conservation 67(6):495-501, doi:10.2489/jswc.67.6.495.

Herzmann, D.E., L.J. Abendroth, and L.D. Bunderson. 2014. Data management approach to multidisciplinary agricultural research and syntheses. Journal of Soil and Water Conservation 69(6):180A-185A, doi:10.2489/ jswc.69.6.180A.

Jin, C.X., G.R. Sands, H.J. Kandel, J.H. Wiersma, and B.J. Hansen. 2008. Influence of Subsurface Drainage on Soil Temperature in a Cold Climate. Journal of Irrigation and Drainage Engineering 134(1):83-88.

Kanwar, R.S., J.L. Baker, and S. Mukhtar. 1988. Excessive Soil Water Effects at Various Stages of Development on the Growth and Yield of Corn. Transactions of the American Society of Agricultural Engineers 31(1):133-141.

Kladivko, E.J., M.J. Helmers, L.J. Abendroth, D. Herzmann, R. Lal, M. Castellano, D.S. Mueller, J.E. Sawyer, R.P. Anex, R.W. Arritt, B. Basso, J.V. Bonta, L. Bowling, R.M. Cruse, N.R. Fausey, J. Frankenberger, P. Gassman, A.J. Gassmann, C.L. Kling, A. Kravchenko, J.G. Lauer, F.E. Miguez, E.D. Nafziger, N. Nkongolo, M. O'Neal, L.B. Owens, P. Owens, P. Scharf, M.J. Shipitalo, J.S. Strock, and M.B. Villamil. 2014. Standardized research transdisciplinary research of climate variation impacts in corn production systems. Journal of Soil and Water Conservation 69(6):532-542, doi:10.2489/jswc.69.6.532.

Kornecki, T.S., and J.L. Fouss. 2001. Quantifying soil trafficability improvements provided by subsurface drainage for field crop operations in Louisiana. Applied Engineering in Agriculture 17(6):777-781.

Kucharik, C.J. 2006. A multidecadal trend of earlier corn planting in the central USA. Agronomy Journal 98:1544-1550.

Lauer, J.G., P.R. Carter, T.M.Wood, G. Diezel, D.W.Wiersma, R.E. Rand, and M.J. Mlynarek. 1999. Corn hybrid response to planting date in the northern Corn Belt. Agronomy Journal 91:834-839.

Powers, W.L., M.L. House, R.D. Tejral, and D.E. Eisenhauer. 1999. A simultaneous data collection system for several soil water release curves. Applied Engineering in Agriculture 15(5):477-481.
Plastina, A. 2014. Current Crop Insurance Policies. Ag Decision Maker. https://www.extension.iastate.edu/ agdm/crops/pdf/a1-48.pdf.

Sands, G.R., I. Song, L.M. Busman, and B.J. Hansen. 2008. The effects of subsurface drainage depth and intensity on nitrate loads in the Northern Cornbelt. Transactions of the American Society of Agricultural and Biological Engineers 51(3):937-946.

SAS. 2011. SAS User's Guide. Ver. 9.3. Cary, NC: SAS Institute, Inc.

Schott, L.R., A. Lagzdins, A.L.M. Daigh, K. Craft, C. Pederson, G. Brenneman, and M.J. Helmers. 2017. Drainage water management effects over five years on water tables, drainage, and yields in southeast Iowa. Journal of Soil and Water Conservation 72(3):251-259, doi:10.2489/jswc.72.3.251.

Skaggs, R.W., and G.M. Chescheir III. 2003. Effects of subsurface drain depth on nitrogen losses from drained lands. Transactions of the American Society of Agricultural and Biological Engineers 46(2):237-244.

Skaggs, R.W., N.R. Fausey, and R.O. Evans. 2012. Drainage water management. Journal of Soil and Water Conservation 67(6):167-172, doi:10.2489/ jswc.67.6.167A.

Steenhuis, T.S., and M.F. Walter. 1986. Will drainage increase spring soil temperatures in cool and humid climates? Transactions of the American Society of Agricultural Engineers 29(6):1641-1645.

Strock, J.S., G.R. Sands, and M.J. Helmers. 2011. Subsurface Drainage Design and Management to Meet Agronomic and Environmental Goals. In Soil Management: Building a Stable Base for Agriculture, eds. J.L. Hatfield and T.J. Sauer, 199-208. Madison, WI: American Society of Agronomy, Crop Science Society of America, and Soil Science Society of America.

Turner, R.E., and N.N. Rabalais. 1994. Coastal Eutrophication near the Mississippi River Delta. Nature 368(6472):619-621. 